\title{
MAIS UM MANUAL DE SINTAXE
}

Felipe de Andrade Constancio

Doutorando em Letras - Língua Portuguesa - pela Universidade do Estado do Rio de Janeiro (UERJ)

Professor de Língua Portuguesa da Secretaria de Estado de Educação do Rio de Janeiro

(SEE-RJ)

felipe.letras.ac@gmail.com

RESENHA

PERINI, Mário Alberto. Sintaxe. São Paulo: Parábola Editorial, 2019.

O mercado editorial das Letras tem produzido em larga escala. Nos últimos dez anos, houve investimento significativo tanto para produção de obras voltadas ao ensino básico quanto para aquelas destinadas ao público universitário. É nesse cenário que surge o manual Sintaxe, de Mário Alberto Perini, professor emérito da Universidade Federal de Minas Gerais.

Trata-se de um manual, portanto, destinado ao público do ensino superior em Letras e a todos aqueles que têm interesse pelo vasto território da sintaxe do português. Sem a pretensão de esgotar todos os tópicos da sintaxe, o professor Perini oferece ao leitor a oportunidade de se debruçar sobre temas instigantes a respeito da estrutura e do funcionamento do português brasileiro em tempo real.

Ao longo dos vinte e dois capítulos, a obra Sintaxe é permeada por itens que sinalizam a longa trajetória do autor pelo território do gerativismo linguístico. Recuperando o tratamento dos constituintes imediatos, em termos de configuração de sentenças aceitáveis do português, o autor traz à tona uma série de questões acerca do 
gênero gramatical em oposição ao gênero natural, assim como a oposição pessoa gramatical versus pessoa da cena discursiva.

Valendo-se de exemplos simples, mas não simplórios, Perini oferece ao leitor pistas valiosas para distinguir aspectos formais e aspectos semânticos na sincronia do português e argumenta em favor da distinção saudável entre esses dois percursos que, se confundidos, põem em conflito uma descrição que se pretenda consistente no âmbito da investigação das línguas.

No produtivo capítulo dos sintagmas, Perini mostra-nos o quão relevante é o conhecimento a respeito das relações sintagmáticas para o pleno desenvolvimento da capacidade de reconhecer funções sintáticas no interior dos períodos do português. Sem prolixidade, mostra-nos que o reconhecimento de sintagmas pode revelar o natural processo de deslocamento, substituição e apagamento dessas unidades no interior das orações.

O tratamento das formas verbais, neste manual, constitui um precioso capítulo sobre as valências verbais (conceituadas como o "conjunto de todas as construções em que um verbo pode ocorrer", segundo o autor). Diferentemente de manuais voltados à gramática tradicional, os verbos aqui não são tratados a partir de seu modelo de conjugação, uma vez que a abordagem ora investida tem estreita relação com a gramática de construções e com os papéis temáticos nos quais são inseridos os verbos, cada um com seu conteúdo argumental específico.

A compreensão dos papéis temáticos é mais uma pista fornecida por Mário Perini ao leitor. Lidando com a transitividade de conteúdo construcional distinto, como a dos verbos "cair" e "comer", Perini sinaliza a multiplicidade de papéis temáticos (entre eles agente e paciente) envoltos na complexa rede de estruturação oracional. Nesse sentido, a 
contribuição construcional para o tratamento dos verbos torna-se uma ferramenta didático-cognitiva para o público leitor.

Outra contribuição que o livro traz está na abordagem dos períodos simples e composto. O autor evidencia para o leitor a noção de que não se dissociam as convergências de ambos, uma vez que a análise na depreensão e descrição do período simples pode ser transposta didaticamente para o reconhecimento de unidades do período composto.

Ainda no capítulo do período composto, o professor Mário Perini retoma uma de suas contribuições à análise das orações principais: não se considera apenas, como oração principal, o segmento antecedente ao conector, já que, para Perini, a oração principal envolve o período integralmente, o que corrobora uma prática de análise sintática do período composto voltada ao conteúdo semântico do todo oracional.

O maior investimento teórico que este manual recebe está na sinalização de que a sintaxe pode ser tratada em interface com estudos de ordem cognitiva, para o benefício de uma análise empírica dos dados da língua. No capítulo "Regras de protótipo e filtros cognitivos", faz-se uma importante menção à teoria dos protótipos, tão cara aos estudos de base cognitivista contemporaneamente.

A aplicação das regras de prototipia (mapeamento de membros representativos em determinadas categorias) ao tratamento das funções sintáticas confere ao manual um avanço ímpar no que concerne aos estudos mais recentes acerca da categorização como um processo imanente à configuração das línguas naturais.

Pertence a esses estudos de categorização, a partir da experiência com a linguagem, a abordagem que Perini confere à sistematização das preposições em cada um dos possíveis sintagmas preposicionados constituintes dos complementos verbais, em 
frases perfeitamente aceitáveis no português do Brasil. A grande pergunta que Perini nos deixa, em paráfrase, é esta: como o usuário da língua dispõe de um repertório de preposições e sabe exatamente o momento em que deve usá-las?

Como este manual é uma obra propositiva, o professor Perini encerra a sua contribuição oferecendo aos leitores mais abordagens que, sem sombra de dúvida, ajudaram a formar muitos linguistas e, portanto, muitos pesquisadores brasileiros. $\mathrm{O}$ manual Sintaxe tem uma importante seção, colocada ao final, para guiar leitores mais interessados no instigante assunto da sintaxe, em suas mais distintas vertentes teóricas.

Não é por menos que todas as obras sugeridas para a leitura são consistentes embasamentos para o estudo do português em território brasileiro (PB). Como nunca deixa de mencionar, o autor pontua que essas obras são fundamentais para o entendimento do que seja a constituição efetiva de um corpus particularmente brasileiro, tratado por especialistas que, desde os anos 1980, vêm investindo em sua sistematização e sua descrição.

Para finalizar a apreciação desta obra, não poderíamos deixar de mencionar o seu caráter didático. Escrita para a seção Linguística para o ensino superior, a obra não perde o seu traço de clareza no tratamento de questões mais complexas no âmbito da sintaxe (um exemplo é o capítulo dos constituintes).

Por meio dos seus exemplos sempre elucidativos, Mário Perini entrega ao público das Letras (sobretudo o iniciante nos estudos da linguagem) um texto palatável e de fácil compreensão. A recente publicação deste manual de Sintaxe mostra-nos que há muito o que se investigar nessas paragens e mostra-nos, ainda, que, após as contribuições gerativistas para o domínio sintático, deve-se trabalhar incessantemente para fazer os 
DOI: $10.12957 /$ palimpsesto.2019.48038

avanços chegarem a um público em formação nas faculdades de Letras, tanto na graduação quanto na pós-graduação. 